\title{
Local knowledge of Sundanese village people on traditional medicine: A case study in Cibeurih Hamlet, Nagarawangi Village, Sumedang District, Indonesia
}

\author{
SINTIAMI RAMADHANI", JOHAN ISKANDAR, RUHYAT PARTASASMITA*, \\ ENENG NUNUZ ROHMATULLAYALY \\ Department of Biology, Faculty of Mathematics and Natural Sciences, Universitas Padjadjaran. Jl. Raya Bandung-Sumedang Km 21, Jatinangor, \\ Sumedang 45363, West Java, Indonesia. Tel./fax.: +62-22-7796412, `email: sintiami12@gmail.com, "pass away
}

Manuscript received: 17 February 2021. Revision accepted: 27 April 2021.

\begin{abstract}
Ramadhani S, Iskandar J, Partasasmita R, Rohmatullayaly EN. 2021. Local knowledge of Sundanese village people on traditional medicine: A case study in Cibeurih Hamlet, Nagarawangi Village, Sumedang District, Indonesia. Biodiversitas 22: 28912898. Traditionally, the Sundanese village people in West Java, Indonesia to treat various common diseases, use traditional medicines made from various plants. The purpose of this study was to describe the knowledge of the Sundanese village people on various diseases, species of medicinal plants and parts of plants used to treat various diseases, sources of medicinal plant species, methods of processing and utilization of medicinal plant species, and source of knowledge on processing and utilization of medicinal plants. The method used in this research was mixed-methods, a mixture of qualitative and quantitative. Data collection techniques were carried out using semistructured interviews with informants, structured interviews with respondents, and field observation. The results showed that there were 22 common diseases suffered by the people of Cibeurih Hamlet, Nagarawangi Village, Sumedang District, West Java Province, Indonesia; 36 species of plants recorded with the most dominant part of the leaf organ being used as medicine by the community; source of medicinal plants species mainly collected from the home garden; as well as the method of processing medicinal plants mostly used by the community. This knowledge is passed on from generation to generation through elderly.
\end{abstract}

Keywords: Disease, local knowledge, traditional medicine, traditional medicine processing

\section{INTRODUCTION}

Local knowledge (LK) or also known as traditional ecological knowledge (TEK) can be interpreted as a collection of knowledge, practices, and beliefs that humans have, for the process of adapting humans to their environment which is the result of heredity through generations, predominantly transmitted by oral using the mother tongue (Berkes 2012). This local knowledge is unique knowledge that is produced from a community culture as a result of trial and error of residents interaction with the environment and the results of personal experience in interacting with their environment (Iskandar 2018). Traditional people interact with nature based on complex systems including the corpus-cosmos-praxis (Toledo 2002). These complex systems operate together as humans fit for the local environment and for utilizing natural sources. The corpus is the knowledge that underlies the deprivation of nature. The cosmos is a belief system that guides the management of natural resources, and praxis is the actual practice of natural resource management (Toledo 2002; Prins and Bassols 2005). Various local knowledge is contained in the traditional community, including knowledge about the types of diseases and traditional treatment methods of those diseases.

People's knowledge of the treatment of a disease is closely related to the use of various traditional medicines found in nature or local ecosystems. One of traditional medicines is made from various species of plants. In general, medical plants are collected from various sources, including home gardens, forests, gardens, and by buying at the market. For example, jukutbau (Ageratum conyzoides L.) and koneng/turmeric (Curcuma domestica Val.) are traditional medicines that are founded in Cibunar Village, West Java. Jukutbau (Ageratum conyzoides L.) is a medicine for stomach aches and wound infection; while koneng/turmeric (Curcuma domestica Val.) is medicine for ulcers. They are collected from home gardens (Suryana and Iskandar 2014).

The local knowledge about traditional medicine in the traditional community is very important, but nowadays local knowledge and natural medicinal ingredients have begun to be displaced by modern knowledge and modern medicine. Another thing is reduced interest of the younger generation in exploring and preserving local knowledge on these traditional medicines and their lack of fluency in using their mother tongue. This causes the inheritance and dissemination of local knowledge about traditional medicine are not well conveyed and gradually become extinct.

This condition is similar to previous research in Cibunar Village (nearby around from Cibeuih hamlet) in 2014 which recorded 132 types of medicinal plants, but now because of the widespread use of modern medicine, the traditional medicine patterns of the people in Cibunar Village have been eroded (Suryana and Iskandar 2014). On 
the other hand, the data of medicinal plants in Riset Tumbuhan Obat dan Jamu (RISTOJA) 2015 in West Java, especially for Cibeurih Hamlet do not exist. Consequently, therefore, the use of traditional medicines derived from plants in Cibeurih Hamlet, Nagarawangi Village, Sumedang District is very important to be investigated. Documentation of the medicinal use of plants through ethnobotanical studies enables the development of contemporary drugs and treatments as well as for plant conservation (Heinrich 2002 and Calzada et al. 2020). Many ethnobotanical studies around the world, including in Indonesia, report the use of herbal plants in the healing process, for several generations in their respective societies (Elfahmi et al. 2014; Sujarwo et al. 2015).

The purpose of this study was to describe the village people's knowledge on various diseases, species of medicinal plants and parts of plants used to treat various diseases, sources of medicinal plants species, methods of processing and using medicinal plants species, and source of knowledge on processing and utilization of medicinal plants.

\section{MATERIALS AND METHODS}

\section{Research sites}

This research was conducted in January-June 2020 and is located in Cibeurih Hamlet, Nagarawangi Village, Rancakalong Sub-district, Sumedang District, West Java Province, Indonesia (Figure 1). Nagarawangi Village is located at 6 $6^{\circ} 55^{\prime} 38.7$ "south latitude and 107\%46'16.8 east longitude. This village consists of three main hamlets, namely the Hamlet of region I, region II, and region III. The research location is in the hamlet of region III called Cibeurih Hamlet (Dusun Cibeurih). Cibeurih Hamlet was purposively chosen based on the results of a preliminary survey which explained that there are still traditional medicine local experts in the hamlet such as indigenous healers (paraji), massage artisans, and other people who know the use of traditional medicinal plants in the area. On the other hand, this research is supported by previous research in Cibunar Village in 2014, which is located nearby of Cibeurih Hamlet, wherein the village there are also medical experts (shaman/paraji) and community leaders who are used as informants in interviews to explore knowledge about traditional medicinal plants (Suryana and Iskandar 2014). In addition, in the hamlet, there are still sources where traditional medicines were found and harvested, including forests, gardens, and home garden (Figure 2).

\section{Research procedure}

The method used in this research is the mixed method, a combination of qualitative and quantitative methods with an ethnobotany approach (Iskandar 2018). The qualitative method was used to understand processes, such as the process of taking traditional medicinal ingredients, the process of concocting traditional medicine, the process of land-use change, and others, while the quantitative method was used to examine the experiences of individuals from a community, such as experiences of suffering from disease, medication, get medicinal ingredients and others (Creswell 2009).

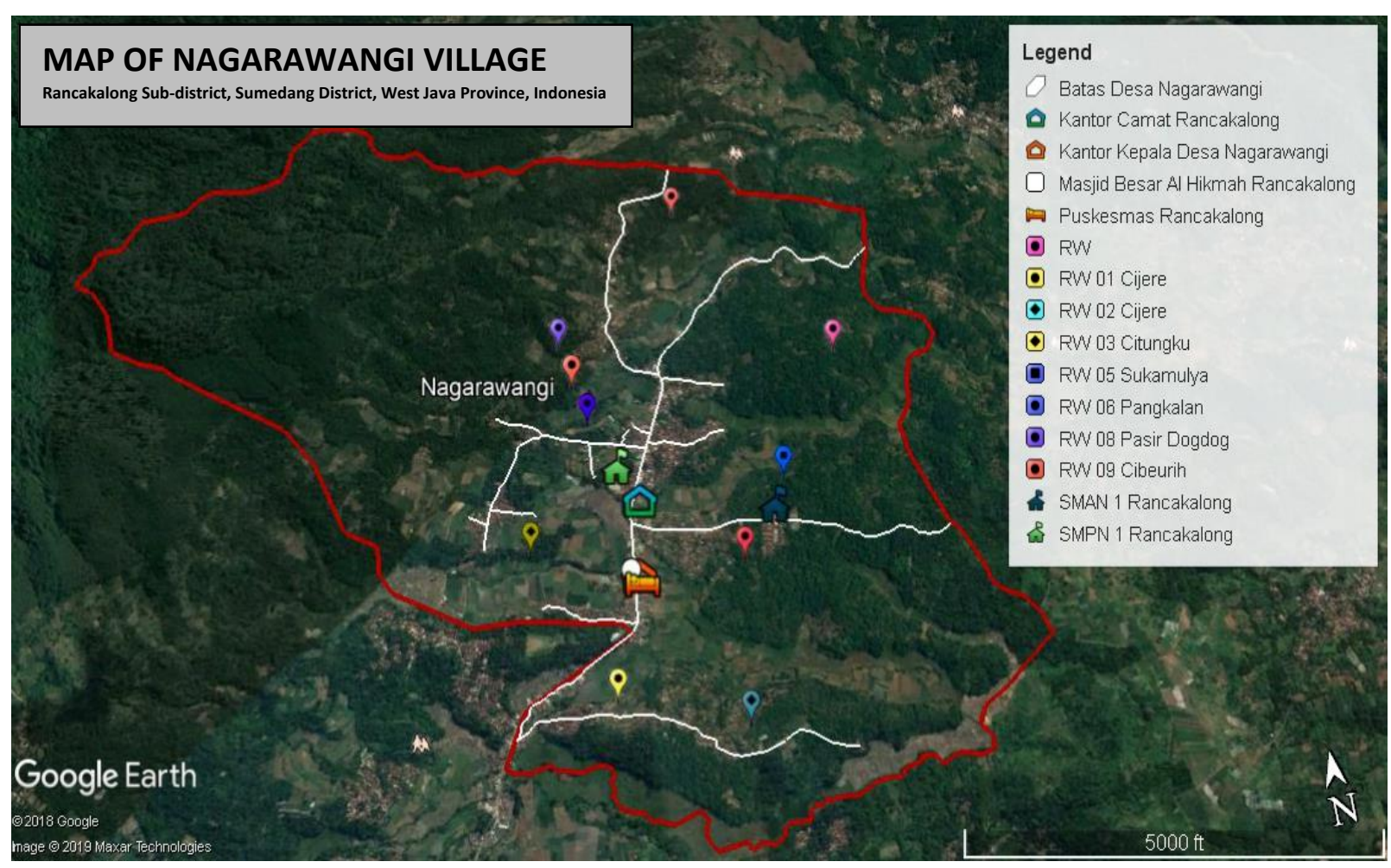

Figure 1. Map of study site at Cibeurih Hamlet, Nagarawangi Village, Rancakalong Sub-district, Sumedang District, West Java Province, Indonesia (Source: Google Image) 

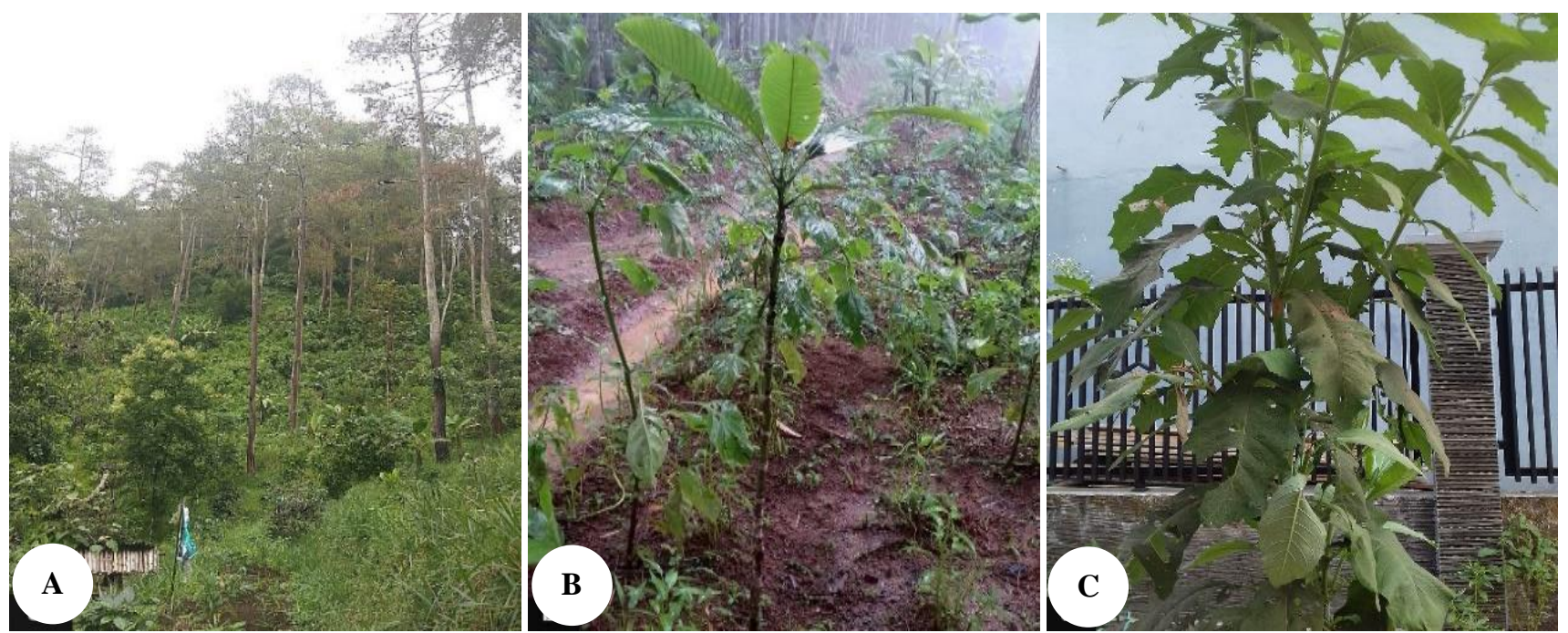

Figure 2. Source of medicinal plant species: A. Forest; B. Garden; C. Home garden

The technique of selecting informants for qualitative methods was carried out purposively based on their competence then continued with the snowball sampling technique, namely asking the base on initial informants. From the initial informants, other informants who are considered competent and different from previous informants can be identified. The obtained informants were 21 people consisting of indigenous healers or shamans (dukun/paraji), traditional birth attendants (dukun bayi), curer who employs herbs, and other native medicine (dukun jampi), informal leaders, and old male and female village people.

Data collection techniques for quantitative methods was done by, first carrying out a census to enumerate the total number of heads of households in the research hamlet, then determining the number of household heads who were represented as respondents using the formula of Lynch et al. (1974), as follows:

$$
n_{t}=\frac{N_{t} \cdot Z^{2} \cdot P(1-P)}{N_{t} d^{2}+Z^{2} \cdot P(1-P)}
$$

$$
\begin{aligned}
& \text { Where: } \\
& n t: \text { Total number of samples (respondents) } \\
& \text { Nt: Total of the household } \\
& \mathrm{Z} \text { : Normal variable value }(1.96) \\
& \text { P: Proportion of greatest probability }(0.50) \\
& \mathrm{d} \text { : sampling error }(0,10)
\end{aligned}
$$

Furthermore, respondents were randomly selected for the study. The obtained respondents were $81 \mathrm{HH}$ (Head of household). Each household head was a respondent and was interviewed using a questionnaire.

Field observations were carried out by observing environmental conditions at the research site, such as conditions of settlements forests, gardens, and home gardens.

\section{Data analysis}

Qualitative analysis is carried out with ethical, emic, crosschecking, summarizing, synthesizing, descriptive- analytical, and evaluative narrative approaches (Newing et al. 2011). Quantitative data analysis was carried out by statistical calculations, namely calculating the frequency in the form of respondents' answers, calculating the percentage of the total respondents, and then making descriptive descriptions of the analysis.

\section{RESULTS AND DISCUSSION}

\section{Types of disease and treatment method}

On the basis of an interview with informants of rural people of Cibeurih Hamlet, Nagarawangi Village, it revealed that the term 'sick' or 'not well' was mentioned in many vernacular names as udur, teu damang, limpeu (teu aya tangan pangawangsa). Symptoms that are felt when the pain occurs are considered as the whole body hurts (teu raraos awak, sagala karasa). Based on the results of the interview, the illness was generally caused by too much activity (tiredness) and age.

Diseases commonly suffered by the rural people of Cibeurih Hamlet, Nagarawangi Village have two categories, namely personalistic and naturalistic. Personalistic may be defined as a disease caused by supernatural beings, nonhuman beings (such as ghosts, spirits, ancestors), or supernatural powers (sorcerers). While, in a naturalistic system, the disease is caused by natural factors. This is in accordance with previous research results that sickness is caused by 'unseen factors' and sickness caused by 'natural factors, such as weather, hot, cold, germs, food, and others (Suryana and Iskandar 2014).

Based on interviews with some informants, it disclosed that there are diseases caused by personalistic factors or commonly known by medical terms, such as witchcraft and, gendam. The reason is due to the entry of supernatural beings and one's revenge against others. In addition, there are 22 types of diseases caused by naturalistic factors, which are commonly suffered by the rural people of Cibeurih Hamlet, Nagarawangi Village. It was traditionally classified as a serious illness and minor illness (Table 1). 
Table 1. Types of common diseases suffered by the people of Cibeurih Hamlet, Nagarawangi Village, Sumedang, Indonesia

\begin{tabular}{lll}
\hline Category & Disease & Cause \\
\hline Serious & Rheumatic & Age \\
illness & Uric acid & Age, Nuts \\
& High blood pressure & Fatty foods, high \\
& cholesterol \\
& Low blood pressure & Food \\
& Fracture & Fall down \\
& Pee pain & Bacteria, viruses \\
& Asthma & Dust, cold temperatures, \\
& Diabetes & bacteria \\
& Typhus & Dietary habit \\
Minor & Cough & Food, Bacteria \\
illness & Ulcer & Viruses, Sweet drinks \\
& Wound & Eat late \\
& Diarrhea & Cut a sharp object \\
& Sore eyes & Spicy food, bacteria \\
& Itchy & Dust, Bacteria \\
& Leucorrhoea & Fungi, Bacteria \\
& & Hormones, Bacterial \\
& Heat & infections \\
& Toothache & Weather, tired \\
& Postpartum (breast milk & Bacteria \\
& is difficult to come out, & Less consumption of \\
& etc.) & vegetables \\
& Back pain & Strenuous activity, age \\
& Headache & Stress, a pattern of life \\
& Flu & Virus \\
\hline & &
\end{tabular}

Based on the results of the questionnaire survey, diseases that were mostly suffered by the people of Cibeurih Hamlet, Nagarawangi Village were rheumatic as much as $31 \%$. According to the respondents, the cause of rheumatic is the age factor, foods such as nuts, green vegetables such as kale, surawung (basil), and the condition of people who make their living as farmers who very commonly complain of pain in the joints, especially in the legs (Figure 3).

According to the informants, generally, diseases caused by personalistic factors are commonly treated by visiting a traditional healer, using some plants and water. For diseases caused by naturalistic factors, treatment is carried out by visiting a doctor such as going to a health center or using traditional medicine and food stalls. This is in line with the respondent's answer to the questionnaire the largest percentage in treating diseases caused by naturalism is by going to a doctor such as a health center or clinic $(63 \%)$. The use of traditional medicines has the smallest percentage, namely $11 \%$, because people rarely mix traditional medicines (Figure 4). The community considers going to a health center/clinic and buying synthetic drugs at a shop are more practical and faster than having to concoct traditional medicines. Because of the traditional healing process in Cibeurih Hamlet is familiar with the term naktu (a prediction of a lucky period or a good day) which the way to treat the disease is by boiling, shredding, brewing, and others (Figure 8).

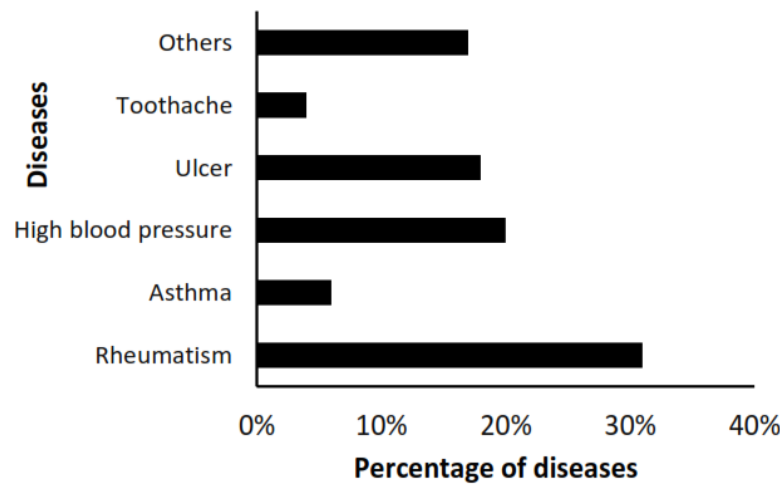

Figure 3. Common diseases affected by the Rural People of Cibeurih Hamlet, Nagarawangi Village, Sumedang, Indonesia

\section{Types of traditional medicinal plants}

Based on the interview with informants, it was documented 36 species of medicinal plants from 24 families are commonly used by the rural community of Cibeurih Hamlet, Nagarawangi Village. These results indicate that plants are quite widely used by the community from forest, garden, and home garden (Table 2).

It can be seen from Figure 5 that the medicinal plant species, including soursop called nangkawalanda (Annona muricata L.) leaves, are the most widely used plant species with the highest percentage of $26 \%$. This plant is used as a medicine for ulcers and high blood pressure. The plant species that had the lowest percentage was gotu kola also called antanan leaves (Centella asiatica L.) at 9\% (Figure 5). Some medicinal plant species including soursop, turmeric, and sembung are commonly found in the homegardens Cibeurih Hamlet, Nagarawangi Village.

\section{Parts of medicinal plants used}

Parts of plants that are used as medicine consist of leaves, roots, stems, bark, rhizomes, tubers, sap. The leaf part is the most widely used by the Cibeurih community (Table 2). This is similar to that of the previous research conducted by Nisyapuri et al. (2018), research on medicinal plants in Wonoharjo Village, Pangandaran District; and Zubair et al. (2019), research in Wombo Village, Central Sulawesi.

In addition, the results of the questionnaire also showed that the leaves were the most frequently used parts with a percentage of $60 \%$ in the leaf organ, while the stems and roots were parts of the plant that were rarely used as a medicine, which was only $1 \%$ (Figure 6). Leaf parts are very commonly used by the community because they are easily found in the surrounding environment and are easily mixed as medicine. This is in line with the research result of Susanti et al. (2018), the part of medicinal beneficial plants that were mostly found was leaves (50 species, $46 \%$ ). Leaves are the major plant components commonly reported to be used as herbal medicine materials in Indonesia and also in other countries (Bradacs et al. 2011; Leto et al. 2013; Umair et al. 2017). Leaves are common and favorite parts used for medicinal treatment preparation because of easy handling and sustainability (Jadid et al. 2020). 


\section{Source of medicinal plants}

Based on the results of interviews with respondents, it revealed that home gardens were recorded as predominant the source of the most medicinal plants $(54 \%)$ while the forests were recorded lowest the source of medicinal plants at least $(3 \%)$ in Cibeurih Hamlet, Nagarawangi Village (Table 2 and Figure 7). This research is similar to that of Supiandi et al. (2019), which states that the cultivated or wild plants for traditional medicine are taken directly from the home garden. The home garden has usually planted a variety of flora that can be used as kitchen herbs. There are also plants domesticated as a source of home medicine (Husain et al. 2019). Today, people also used traditional medical plant such as empon-empon (ingredients is ginger, turmeric) to increase endurance/immunity. Thus, the increasing population and consumer interest in natural and medicinal products have supported an increase in market demand for medicinal plant products (Handriatni 2020).

\section{Processing and utilization of medicinal plants}

Based on an interview with informants of Cibeurih Hamlet community, Nagarawangi Village, it can be seen that the using and cultivating medicinal plants have been undertaken for a long time, this knowledge is generally inherited from generation to generation from parents and neighbors. Based on the results of interviews with the Cibeurih Hamlet community, in the processing of medicinal plants, people are familiar with the term naktu (prediction of lucky time or good day). This time is in the

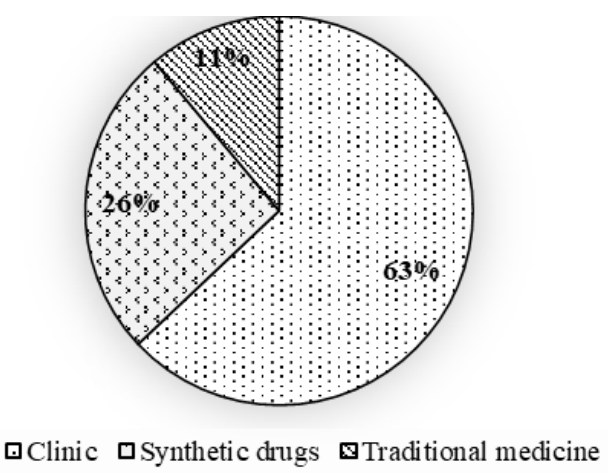

Figure 4. How to treat diseases in Cibeurih Hamlet, Nagarawangi Village, Sumedang, Indonesia

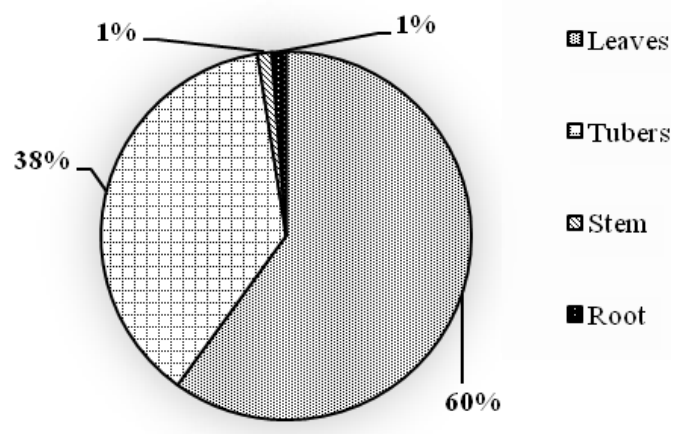

Figure 6. Parts of plants that are commonly used by the People of Cibeurih Hamlet, Nagarawangi Village, Sumedang, Indonesia form of a rule in this case picking plants, which is considered to be as a good day. For example, on Sunday 5 pieces or bets are picked, while on Monday picking 4 bets. While Tuesday, Wednesday, Thursday, Friday, and Saturday picking 3, 7, 8, 6, and 9 bets, respectively.

Furthermore, based on the results of the questionnaire with respondents on how to process medicinal plants commonly used by the community, it can be revealed that boiling was predominant with a percentage of $72 \%$. Processing by boiling has the highest percentage because it is considered effective by the community in curing a disease, where bioactive compounds in plants can dissolve in the extract of the stew. The method of processing medicinal plants by brewing has the lowest percentage, namely 7\% (Figure 8). This method is intended for all nutritious substances contained in the material can dissolve into boiling water (extraction process) (Sumarni et al. 2019).

\section{Source of knowledge on processing and utilization of medicinal plants}

Based on the results of the questionnaire with respondents of Cibeurih Hamlet community regarding the source of knowledge on processing and utilization of medicinal plants, it can be inferred that $60 \%$ of respondents obtained the knowledge from their parents. Moreover, $36 \%$ they obtained from neighbors/others, and as many as $4 \%$ of respondents said they did not know this information (Figure 9).

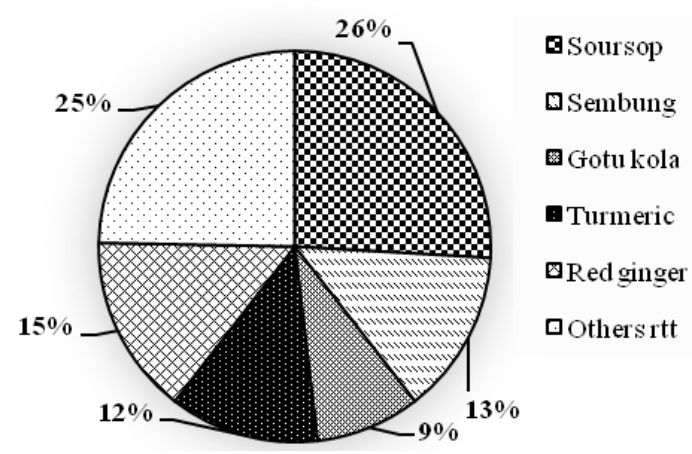

Figure 5. Types of medicinal plants commonly used by the people of Cibeurih Hamlet, Nagarawangi Village, Sumedang, Indonesia

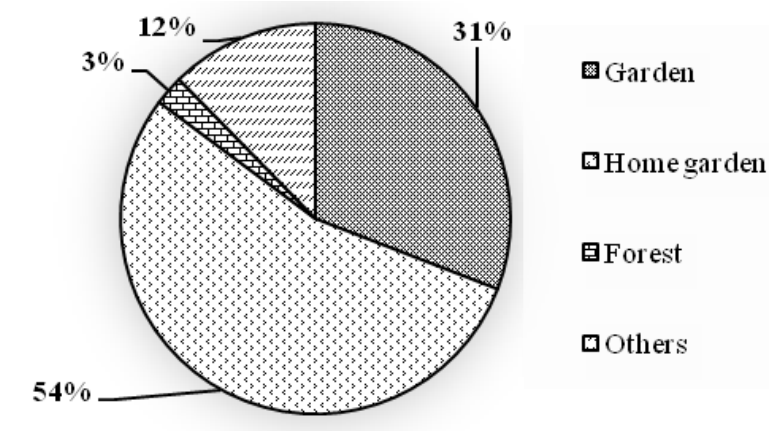

Figure 7. Source of medicinal plants in Cibeurih Hamlet, Nagarawangi Village, Sumedang, Indonesia 
Table 2. Types, parts and utilization of medicinal plants

\begin{tabular}{|c|c|c|c|c|c|c|}
\hline Vernacular name & Scientific & Family & Part & Efficacy & Source location & How to Process \\
\hline Antanan & Centella asiatica $\mathrm{L}$. & Apiaceae & Leaf & Ulcer, gout, rheumatic & Home garden & Boiled \\
\hline Bawang bodas & Allium sativum $\mathrm{L}$. & Alliaceae & Bulbs & Toothache, & Home garden & Digeprek (Pounded) \\
\hline Beluntas & Pluchea indica $\mathrm{L}$. & Asteraceae & Leaf & Leucorrhoea & Home garden & Boiled \\
\hline Belimbing & Averrhoa carambola $\mathrm{L}$. & Oxalidaceae & Leaf & Medicine for headache & Home garden & Boiled \\
\hline Bintinu & Melochia sp. & Sterculiaceae & Leaves, bark & Broken bone as a cast & Home garden & Bandaged \\
\hline Cangkoreh & Dinochloa scandens K. & Poaceae & Roots stems & Sore eyes, cough & Forest & Dituak (Dripped) \\
\hline Cau & Musa $x$ paradisiaca $\mathrm{L}$. & Musaceae & Leaves, sap & $\begin{array}{l}\text { Wounds medicine, diarrhea in babies, itching } \\
\text { medicine }\end{array}$ & Garden & Digaleuy (Squeezed) \\
\hline Madinah/dedi & Abelmoschus manihot $\mathrm{L}$. & Malvaceae & Leaf & Heat & Home garden & Digaleuy (Squeezed) \\
\hline Ki urat & Plantago major L. & Plantaginaceae & Leaf & Gout, wounds, ulcers & Home garden & Boiled, digaleuy (Squeezed) \\
\hline Kumis ucing & Orthosiphon stamineus B. & Lamiaceae & Leaf & Difficulty urinating, back pain & Home garden & Boiled \\
\hline Kalingsir & Clinacanthus nutans B. & Acanthaceae & Leaf & Back pain, hard to pee & Home garden & Boiled, brewed \\
\hline Jarak & Jatropha curcas L. & Euphorbiaceae & Leaves, sap & Diarrhea medicine, toothache & Home garden & Digaleuy, smeared \\
\hline Jahe & Zingiber officinale $\mathrm{R}$. & Zingiberaceae & Rhizome & Ulcer medicine/ nausea & Home garden & Pounded \\
\hline Jahe bereum & Zingiber officinale var. rubrum $\mathrm{T}$. & Zingiberaceae & Rhizome & Rheumatic drugs, postpartum & Home garden & Pounded \\
\hline Jambu kulutuk & Psidium guajava $\mathrm{L}$. & Myrtaceae & Leaf & Diarrhea medicine & Home garden & Dileob (brewed), boiled \\
\hline Kelor & Moringa oleifera Lam. & Moringaceae & Leaf, & Eye pain, high blood pressure & Home garden & Kneaded, brewed \\
\hline Koneng & Curcuma domestica Val. & Zingiberaceae & Rhizome & Ulcer medication & Home garden & Shredded \\
\hline Ki beling & Sericocalyx crispus $\mathrm{L}$. & Acanthaceae & Leaf & Pee pains & Home garden & Brewed \\
\hline Salam & Syzygium polyanthum $\mathrm{W}$. & Myrtaceae & Leaf & High blood medication & Home garden & Boiled \\
\hline Nangka walanda & Annona muricata $\mathrm{L}$. & Annonaceae & Leaf & $\begin{array}{l}\text { Medication for high blood pressure, chills, } \\
\text { ulcers }\end{array}$ & Home garden, garden & Boiled \\
\hline Sampeu & Manihot esculenta $\mathrm{C}$. & Euphorbiaceae & Leaf & Low blood medicine, ulcer & Home garden, garden & Boiled \\
\hline Seureuh & Piper betle L. & Piperaceae & Leaf & Dental eye medicine & Home garden & Chewed, kneaded \\
\hline Sembung & Blumea balsamifera DC & Asteraceae & Leaf & Postpartum, & Home garden & Dileob (brewed), boiled \\
\hline Godobos & Sonchus arvensis L. & Asteraceae & Leaf & Urinating, rheumatic, postpartum & Home garden & Boiled \\
\hline Saliara & Lantana camara L. & Verbenaceae & Leaf & Hypertension, ulcer/patuangan & Home garden & Boiled \\
\hline Awisurat & Gigantochloa verticillata Schrad & Poaceae & Trunk & Cough medicine & Forest & Dituak (dripped) \\
\hline Limus & Mangifera foetida $\mathrm{L}$. & Anacardiaceae & Leaf & Hot and cold herb medicine & Forest & Boiled \\
\hline Jeruk cikoneng & Citrus maxima Merr. & Rutaceae & Leaf & Hot and cold herb medicine & Forest, garden & Boiled \\
\hline Alpukat & Persea americana $\mathrm{M}$. & Lauraceae & Leaf & High blood pressure, rheumatic & Home garden & Boiled \\
\hline Seureuh wangi & Cymbopogon nardus L. (Rendle) & Poaceae & Leaf & Hot and cold herb medicine & Home garden & Boiled \\
\hline Jukut bau & Ageratum conyzoides $\mathrm{L}$. & Asteraceae & Leaf & Stomach pain/diarrhea, wounds & Home garden & Squeezed, chewed \\
\hline Buntiris & Kalanchoe sp. & Crassulaceae & Leaf & Heat & Home garden & Boiled \\
\hline Binahong & Anredera cordifolia (Ten). Steenis. & Basellaceae & Leaf & Heat, Rheumatic, diabetes & Home garden & Boiled, \\
\hline Bawang bereum & Allium cepa $\mathrm{L}$. & Amaryllidaceae & Bulbs & Heat, Flu, Eyes & Garden & Squeezed \\
\hline Taleus hideung & Xanthosoma sp. & Araceae & Sap & Wound & Home garden & Cut off \\
\hline Surawung & Ocimum sanctum $\mathrm{L}$. & Lamiaceae & Leaf & Cough & Home garden & Brewed \\
\hline
\end{tabular}




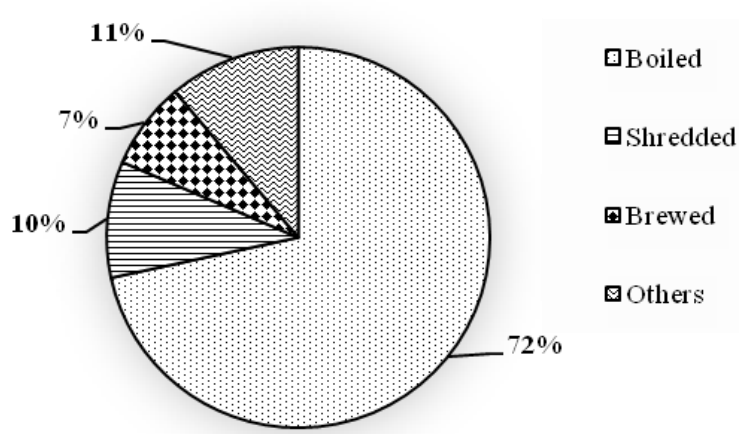

Figure 8. The most commonly used medicinal plant processing method in Cibeurih Hamlet, Nagarawangi Village, Sumedang, Indonesia

Based on this research, it is now generally recognized that the rural people of Cibeurih Hamlet, Nagarawangi Village have more knowledge on processing and utilization of medicinal plants inherited from their parents from generation to generation through oral using mother language without written documentation. Until this research was a conducted, no data on community exploration effort in Cibeurih Hamlet that document this knowledge.

This result is similar to Puri (1997), in that it has there are three ways of distribution of local knowledge in the traditional community, namely by parental learning (from parents), peer learning (from peer group), and individual learning (from individual experiences). In other words, unlike Western knowledge, the local knowledge has characteristics, including very local, orally, holistic, integrative, and situated within broader cultural traditions and inherited by oral using mother language, including predominantly inherited through parents (Ellen and Harris 2000). In addition, traditionally it has been also mentioned that the knowledge of the use of the plants as medicine is obtained from parents, community members, and ancestors who come to them in dreams. This knowledge is delivered orally only to the people who are believed to be able to live the spirit through customary rituals (Supiandi et al. 2019).

In conclusion, the common diseases suffered by the people of Cibeurih Hamlet, Nagarawangi Village are divided into two disease factors, including personalistic and naturalistic diseases. Personalistic factors (unseen factors) consist of witchcraft and gendam. Naturalistic factors (natural factors) recorded 22 types of diseases, which are divided into serious diseases and minor diseases. There are 36 species of medicinal plants from 24 families, with the most commonly used plant parts in the form of leaves. These medicinal plants are found mostly in the home garden. As for the processing and utilization methods of medicinal plants that are most commonly used, namely by boiling. Knowledge about medicinal plants, their management, and their use are obtained by the community from generation to generation through predominant parents. Thus, our research helps the community to document knowledge about the processing and utilization of traditional medicinal plants used in the hamlet so that knowledge is not easily eroded.

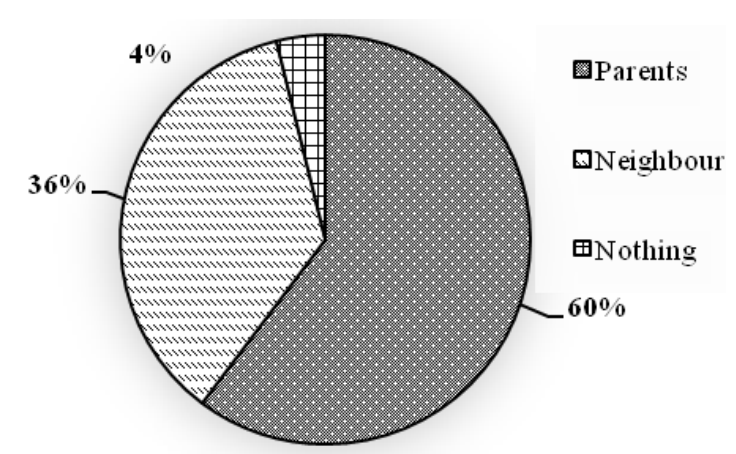

Figure 9. Sources of knowledge on the processing and utilization of traditional medicines of the Ciberih Hamlet Community, Nagarawangi Village, Sumedang, Indonesia

Other important aspects, including herbal treatment profiles, carried out by informants such as number of patients the frequency of treating patients, etc actually must be studied. However, those aspects have not been studied in this research and are considered to be our suggestion for continuing study on ethnobotany and ethnomedicine in near future.

\section{ACKNOWLEDGEMENTS}

This research would not have been possible without the academic supports of Dean of the Faculty of Mathematics and Natural Sciences Unpad, the head of the Biology study program. We would like to thank the Rector of Unpad who financially supported for researching the field through the Academic Leadership Program (ALG) program of Prof. Johan Iskandar. We also would like to thank the people of Cibeurih Hamlet, Nagarawangi Village who have assisted during the research process.

\section{REFERENCES}

Berkes F. 2012. Sacred Ecology. 3rd ed. Routledge, New York. DOI: $10.4324 / 9780203123843$

Bradacs G, Heilmann J, Weckerle CS. 2011. Medicinal plant use in Vanuatu: A comparative ethnobotanical study of three islands. J Ethnopharmacol 137 (1): 434-448. DOI: 10.1016/j.jep.2011.05.050

Calzada F, Bautista E. 2020. Plants used for the treatment of diarrhoea from Mexican flora with amoebicidal and giadicidal activity, and their phytochemical constituents. Ethnopharmacol 253: 1-14. DOI: 10.1016/j.jep.2020.112676

Creswell JW. 2009. Research Design: Qualitative, Quantitative, and Mixed Methods Approaches. Sage Publications, Newbury Park.

Elfahmi, Woerdenbag H, Kayser O. 2014. Jamu: Indonesian traditional herbal medicine towards rational phytopharmacological use. J Herbal Med 4 (2): 51-73. DOI: 10.1016/j.hermed.2014.01.002

Ellen R, Harris H. 2000. Introduction. In Indigenous Environmental Knowledge and its Transformations: Critical Anthropological Perspectives. In: Ellen R, Parkes P, Bicker A (eds.) Harwood, Amsterdam.

Handriatni A. 2020. Farm from home, optimizing yard with "emponempon planting" as effort to maintain body resistance (immunity) in the middle and post covid 19. Pena Jurnal Ilmu Pengetahuan dan Teknologi 34 (2): 67-73. [Indonesian] 
Heinrich M. 2000. Ethnobotany and its role in drug development Phytotherapy Res 14 (7): 479-488. DOI: 10.1002/1099 1573(200011)14:7<479::AID-PTR958>3.0.CO;2-2

Husain F, Fajar DP, Sary, Yuniati E. 2019. The study of jamu plants ethnobotany in home garden and its implications to medicinal plant conservation in Semarang. Proceedings of the $1^{\text {st }}$ International Conference on Environment and Sustainability Issues, Semarang State University, Semarang, 18-19 July 2019. DOI: 10.4108/eai.18-72019.2290185

Iskandar J. 2018. Ethnobiology, Ethnoecology and Sustainable Development. Plantaxia, Yogyakarta. [Indonesian]

Jadid N, Kurniawan E, Himayani CES, Andriyani, Prasetyowati I, Purwani KI, Muslihatin W, Hidayati D, Tjahjaningrum ITD. 2020. An ethnobotanical study of medicinal plants used by the Tengger tribe in Ngadisari Village, Indonesia. Plos One15 (7): 1-16. DOI: 10.4108/eai.18-7-2019.2290185

Leto C, Tuttolomondo T, La Bella S, Licata M. 2013. Ethnobotanical study in the Madonie Regional Park (Central Sicily, Italy)-Medicinal use of wild shrub and herbaceous plant species. J Ethnopharmacol 146 (1): 90-112.

Lynch S. 1974. Data Gathering by Social Survey. Philippine Social Science Council, Quezon City.

Newing H, Eagle CM, Puri RK, Watson CW. 2011. Conducting Research in Conservation: A Social Science Perspective. Routledge, London. DOI: $10.4324 / 9780203846452$

Nisyapuri FF, Iskandar J, Partasasmita R. 2018. Ethnobotany study of medicinal plants in Wonoharjo Village, Pangandaran District, West Java. Pros Sem Nas Masy Biodiv Indon 4 (2): 122-132. [Indonesian]

Prins AMGAW, Bassols NB. 2005. Introduction: ethnoecology. J Latin Am Geograph 4 (1): 7-8. DOI: 10.1353/lag.2005.0032
Puri RJ. 1997. Hunting Knowledge of the Penan Benalui of East Kalimantan, Indonesia. [Dissertation]. Department of Anthropology, University of Hawaii, Hawaii.

Sujarwo W, Keim AP, Savo V, Guarrera PM, Caneva G. 2015. Ethnobotanical study of Loloh: Traditional herbal drinks from Bali (Indonesia). J Ethnopharmacol 169: 34-48. DOI: 10.1016/j.jep.2015.03.079

Sumarni W, Sudarmin S, Sumarti SS. 2019. The scientification of jamu: a study of Indonesian's traditional medicine. J Phys 1321 (3): 1-7. DOI: 10.1088/1742-6596/1321/3/032057.

Supiandi MI, Mahaanal S, Zubaidah S, Julung H, Ege B. 2019. Ethnobotany of traditional medicinal plants used by Dayak Desa Community in Sintang, West Kalimantan, Indonesia. Biodiversity 20 (5): 1264-1270. DOI: 10.13057/biodiv/d200516.

Suryana Y, Iskandar J. 2014. Study of local knowledge of medicinal plants in home garden agroecosystems and the dynamics of change in Cibunar Village, Rancakalong District, Sumedang District, West Java. Bionatura-J Life Physic Sci 15 (3): 203-209. [Indonesian]

Susanti AD, Wijayanto N, Hikmat A. 2018. Diversity of medicinal plant species in Repong Damar Krui Agroforestry, Lampung Province. Conserv Media 23 (2): 162-168.

Toledo VM. 2002. Ethnoecology: A Conceptual Framework for the Study of Indigenous Knowledge of Nature. In: Stepp JR, Wyndham FS, Zarger RK (eds) Ethnobiology and Biocultural. The International Society of Ethnobiology, Georgia.

Umair M, Altaf M, Abbasi AM. 2017. An ethnobotanical survey of indigenous medicinal plants in Hafizabad district, Punjab-Pakistan. PLoS One 12 (6): e0177912. DOI: 10.1371/journal.pone.0177912.

Zubair, Suleman SM, Ramadhanil. 2019. Studi etnobotani tumbuhan obat pada Masyarakat Kaili Rai di Desa Wombo, Kecamatan Tanantovea, Kabupaten Donggala, Sulawesi Tengah. Biocelebes 13 (2): 182-194. [Indonesian] 